\title{
Venlafaxine Measurement
}

National Cancer Institute

\section{Source}

National Cancer Institute. Venlafaxine Measurement. NCI Thesaurus. Code C147444.

The determination of the amount of venlafaxine present in a sample. 